\title{
Development and Validation of an Ultra Performance Liquid Chromatography Method for the Determination of Dexketoprofen Trometamol, Salicylic Acid and Diclofenac Sodium
}

\author{
Deksketoprofen Trometamol, Salisilik Asit ve Diklofenak Sodyum \\ Etkin Maddeleri için Ultra Performanslı Sıvı Kromatografisi Yönteminin \\ Geliştirilmesi ve Validasyonu
}

Sibel ILBASMIŞ TAMER

Gazi University, Faculty of Pharmacy, Department of Pharmaceutical Technology, Ankara, Turkey

\begin{abstract}
Objectives: A simple, fast, accurate and precise method has been developed for the determination of dexketoprofen trometamol (DKP), salicylic acid (SA) and diclofenac sodium (DIC) in the drug solutions using ultra high performance liquid chromatography (UPLC).

Materials and Methods: UPLC method is highly reliable and sensitive method to quantify the amount of the active ingredient and the method is validated according to $\mathrm{ICH}$ guidelines.

Results: The developed method is found to be precise, accurate, specific and selective. The method was also found to be linear and reproducible. The value of limit of dedection (LOD) of DKP, SA, DIC were found $0.00325 \mu \mathrm{g} / \mathrm{mL}, 0.0027 \mu \mathrm{g} / \mathrm{mL}$ and $0.0304 \mu \mathrm{g} / \mathrm{mL}$, respectively. The limit of quantitation (LOQ) of DKP, SA and DIC were found $0.00985 \mu \mathrm{g} / \mathrm{mL}, 0.0081 \mu \mathrm{g} / \mathrm{mL}$ and $0.0920 \mu \mathrm{g} / \mathrm{mL}$, respectively.

Conclusion: Proposed methods can be successfully applicable to the pharmaceutical preparation containing the above mentioned drugs (dexketoprofen trometamol, salicylic acid and diclofenac sodium). Even very small amounts of active substance can be analyzed and validations can be performed easily.
\end{abstract}

Key words: Dexketoprofen trometamol, salicylic acid, diclofenac sodium, UPLC, validation

ÖZ

Amaç: Deksketoprofen trometamol (DKP), salisilik asit (SA) ve diklofenak sodyumun (DIC) ilaç çözeltisindeki analizi için ultra yüksek basınçlı sıvı kromatografisi (UPLC) kullanılarak basit, hızlı, doğru ve kesin bir yöntem geliștirilmiştir.

Gereç ve Yöntemler: UPLC yöntemi aktif bileșikleri analiz etmek için oldukça hassas bir yöntemdir ve yöntem ICH kurallarına göre valide edilmiştir. Bulgular: Geliştirilen yöntem, kesin, doğru, spesifik ve seçici bulunmuştur. Yöntem, doğrusal ve tekrarlanabilir bulunmuştur. DKP maddesi için teşhis sınırı-duyarlıık sınırı (LOD) $0.00325 \mu \mathrm{g} / \mathrm{mL}$ ve tayin alt sınırı-saptama sınırı (LOQ) $0.00985 \mu \mathrm{g} / \mathrm{mL}$ olarak bulunmuştur. SA için LOD 0.0027 $\mu \mathrm{g} / \mathrm{mL}$ ve $L O Q 0.0081 \mu \mathrm{g} / \mathrm{mL}$ olarak bulunmuştur. DIC için LOD $0.0304 \mu \mathrm{g} / \mathrm{mL}$ ve $L O Q 0.0920 \mu \mathrm{g} / \mathrm{mL}$ olarak bulunmuştur.

Sonuç: Böylece önerilen yöntemler yukarıda bahsedilen ilaçları içeren (deksketoprofen trometamol, salisilik asit ve diklofenak sodyum) farmasötik preparatlarda başarılı bir şekilde uygulanabilecektir. Aktif bileşikler çok küçük miktarlarda analiz edilebilecek ve kolaylıkla valide edilebilecektir.

Anahtar kelimeler: Deksketoprofen trometamol, salisilik asit, diklofenak sodyum, UPLC, validasyon 


\section{INTRODUCTION}

Dexketoprofen trometamol (DKP) chemically, 2-amino2-(hydroxymethyl) propane-1,3-diol; 2-(3-benzoylphenyl propionic acid is a water-soluble salt of the (S)-(+)- enantiomer of the non-steroidal anti-inflammatory drug (NSAID) ketoprofen. ${ }^{1}$ The enantiomer is a relatively new oral NSAID with analgesic, anti-inflammatory and anti-pyretic properties and is one of the most potent in vitro inhibitors of prostaglandin synthesis. ${ }^{2}$ DKP is a new, quick acting analgesic for the treatment of painful musculoskeletal conditions such as osteoarthritis and low back pain. It is also used as a treatment for post-operative pain, toothache and dysmenorrhea. ${ }^{3}$ It is the active optical isomer (eutomer) of ketoprofen, a propionic acid NSAID. The eutomer has been separated to halve the dosage required and halve the metabolic load. The inactive isomer (distomer) has been discarded in the hope of eliminating or reducing potential unnecessary side effects ${ }^{4}$ (Graphic 1 ).<smiles>C[C@@H](C(=O)O)c1cccc(C(=O)c2ccccc2)c1</smiles>

Dexketoprofen trometamol ${ }^{5}$

Salicylic acid (SA) is aminohydroxybenzoic acid, a type of phenolic acid and a beta hydroxy acid. It has the formula $\mathrm{C}_{7} \mathrm{H}_{6} \mathrm{O}_{3}$. SA is the most widely consumed analgesic, antipyretic, and antiinflammatory agent in the World. ${ }^{6}$ It is a natural product found in the bark of a willow tree and has been used to relieve fever and pain. ${ }^{7}$ SA is a precursor to acetylsalicylic acid, better known as aspirin. ${ }^{8}$ SA is used topically for its keratolytic, bacteriostatic, fungicidal, and photoprotective properties. Topical application has been shown to reduce the rate of keratinocyte proliferation. It also inhibits cholesterol sulfotransferase, an enzyme responsible for cholesterol sulfate formation within keratinocytes. SA directly solubilizes the stratum corneum by dissolving the intercellular cement. Through these mechanisms, SA increases the elimination of squames from the stratum corneum. ${ }^{9}$ The principal use of topical SA in dermatology is as a keratolytic agent. SA toxicity can occur with topical use of $6 \%$ SA over as little as $40 \%$ body surface area. ${ }^{10}$

Diclofenac (DIC) sodium is chemically 2-[2-(2,6dichlorophenylamino)phenyl] acetic acid, a NSAID exhibits anti-inflammatory and analgesic properties. The primary mechanism responsible for its anti-inflammatory, antipyretic, and analgesic action is thought to be inhibition of prostaglandin synthesis by inhibition of cyclooxygenase (Graphic 2).

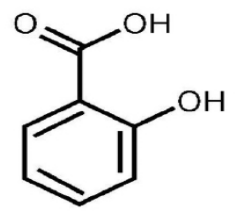

Salicylic acid ${ }^{8}$
It also appears to exhibit bacteriostatic activity by inhibiting bacterial DNA synthesis ${ }^{11}$ (Graphic 3).<smiles>NOC(=O)Cc1ccccc1Nc1c(Cl)cccc1Cl</smiles>

Diclofenac sodium ${ }^{12}$

The chosen data from literature sources are shown in Table $1 .{ }^{13,14,15}$ It is well known that DKP is highly soluble in water and class 1 group compound according to the biopharmaceutical classification system. Permeability is also high. ${ }^{16}$ SA is class 1 compound, and highly soluble in water. ${ }^{17}$ DIC has poor water solubility and high permeability as class 2 compound. ${ }^{18}$ The solubility, permeability properties, molecular weights, melting points, ionization constants and octanol-water partition coefficient of active ingredients are different from each other. The ultra performance liquid chromatography (UPLC) methods were developed of these different active ingredients.

Although several high-performance liquid chromatography methods can be found in the literature for DKP, SA and DIC to date, there is a few UPLC methods for aforementioned active ingredients. In the present investigation, a simple, optimized, and validated UPLC methods were proposed for the standardization of DKP, SA, DIC. The aim of this study was to develop and validate an analytical method for DKP, SA, DIC in buffer solution. Methods validation is the process of demonstrating that analytical procedures are suitable for their intended use, to ensure the identity, strength, quality, purity, and potency of the drug substance and drug product. ${ }^{19,20}$ Linearity, accuracy, repeatability, specificity, sensitivity and detection limit parameters were validated by examining these parameters.

\section{EXPERIMENTAL}

Materials

DKP was purchased Huangshi Shixing Pharmaceutical Co. Ltd. (China). SA was purchased from Botafarma Pharmaceutical Laboratory (Turkey) and DIC was obtained from Fako Pharmaceuticals, Inc. (Düzce, Turkey).

Acetonitrile, methanol, ammonium chloride, monosodium phosphate and disodium phosphate were purchased fom Merck Darmstadt (Germany). Acetone was purchased from Sigmaaldrich, MO, (USA), potassium dihydrogen phosphate was purchased from Reidel-deHaën, (Germany), distilled water (18 MW.cm).

\section{Instrumentation}

Waters Acquity, UPLC system was used (MA, USA). Inertsil (ODS-4, GL Sciences, 2 m, 2.1×50 mm, C/N 5020-81202, S/N OFF50005) was used as a UPLC colon. Diode array dedector was used. 
Table 1. Used physicochemical properties of the active ingredients ${ }^{13,14,15}$

\begin{tabular}{l|l|l|l|l|l} 
& Molecular weight $(\mathrm{g} / \mathrm{moL})$ & Topological polar surface are ${ }^{(A 2)}$ & Melting point $\left({ }^{\circ} \mathrm{C}\right)$ & Log P (Oct/water) & Pka \\
\hline Dexketoprofen & 375.4 & 141 & 104 & 3.36 & 3.88 \\
\hline Salicylic acid & 138 & 57.5 & 159 & 2.26 & 2.97 \\
\hline Diclofenac & 318 & 52.2 & 275 & 4.40 & 3.80 \\
\hline
\end{tabular}

Pka: Lonization constant

Ultra performance liquid chromatography assay method and validation of active ingredients

UPLC method was developed to quantify the drug in the saturated drug solutions. Active ingredients were dissolved in $25 \% \mathrm{pH} 7.4$ sodium phosphate buffer. To prepare phosphate buffer at $\mathrm{pH} 7.4 ; \mathrm{KH}_{2} \mathrm{PO}_{4}(250 \mathrm{~mL}, 0.2 \mathrm{M}$ ) was prepared, then $0.2 \mathrm{M} \mathrm{NaOH}$ (195.5 $\mathrm{mL}$ ) was mixed and completed to 1 liter with deionized water. Then, dilution was made with deionized water. The purpose of $25 \%$ diluting the buffer solution is to reduce ion concentration of solution thereby facilitating the analysis of the active substance. After dilution was checking whether there is change in $\mathrm{pH}$. It was determined that the $\mathrm{pH}$ of the environment remains constant.

Ultra performance liquid chromatography assay method and validation of dexketoprofen trometamol

UPLC methods and conditions of DKP was adopted and validated. 2,4,5,21 The method was found to be linear and reproducible. The $A$ solvent was acetonitrile and the $B$ solvent was $\mathrm{MeOH} /$ Water (1/1) (v/v). Starting conditions were $98 \% \mathrm{~B}$, and within two min $30 \% \mathrm{~B}$ was employed. The final condition is $98 \% \mathrm{~B}$. The temperature was $25^{\circ} \mathrm{C}$. Ultraviolet (UV) absorbance data were collected at $254 \mathrm{~nm}$. The flow rate was $0.25 \mathrm{~mL} / \mathrm{min}$. The retention time was $0.734 \mathrm{~min}$. Injection volume was $20 \mu \mathrm{L}$.

Ultra performance liquid chromatography assay method and validation of salicylic acid

UPLC method of SA was also adopted from literature and validated. $22,23,24,25$ The gradient mobile phase flow was almost same with dexketoprofen analysis. The temperature was $25^{\circ} \mathrm{C}$. UV absorbance data were collected at $292 \mathrm{~nm}$. The flow rate was $0.25 \mathrm{~mL} / \mathrm{min}$. The retention time was $0.704 \mathrm{~min}$. Injection volume was $20 \mu \mathrm{L}$.

Ultra performance liquid chromatography assay method and validation of diclofenac sodium

UPLC method and conditions for DIC was also adopted.11,12,26,27 The A solvent was acetonitrile and B solvent was $50 \mathrm{mM}$ acetate buffer (1/1), (v/v) $\mathrm{pH}$ 3.1. The column temperature was stable at $25^{\circ} \mathrm{C}$. UV absorbance data were collected at $254 \mathrm{~nm}$. The flow rate was $0.5 \mathrm{~mL} / \mathrm{min}$. The retention time was $1.22 \mathrm{~min}$. Injection volume was $20 \mu \mathrm{L}$. The method used was found to be reproducible. Injection volume was $20 \mu \mathrm{L}$.

\section{Real sample applications}

To evaluate the performance of the proposed method, real sample application was performed using commercial tablet, test tablet and commercial eye drop. Test tablets were prepared with SA, lactose, starch 1500, magnesium stearate, aerosil 200. The brand name of commercial DKP tablet is Arveles ${ }^{\circledR} 25 \mathrm{mg}$ film tablets. The brand name of commercial DIC eye drop is Inflased ${ }^{\circledR} 1 \%, 5 \mathrm{~mL}$. In this scope, the amounts of DKP, SA and DIC were determined in commercial tablet, test tablet and eye drop, respectively.

Ten tablets (each tablet containing $36.9 \mathrm{mg}$ DKP) were weighed and finally powdered. A portion of powder equivalent to about $36.9 \mathrm{mg}$ DKP was weighed accurately and dissolved completely in exact volume of $369 \mathrm{~mL}$ phosphate buffered saline (PBS). Then, solution was stirred for 154 min on a magnetic stirrer. The solution was filtered and diluted with PBS up to mark. 20 $\mu \mathrm{L}$ volume of sample solution was injected into the column.

Ten tablets (each tablet containing 1\% SA) were weighed and finally powdered. A portion of powder equivalent to about 1.5 mg SA was weighed accurately and $300 \mu \mathrm{L}$ dimethyl sulfoxide added, transferred to a $25 \mathrm{~mL}$ volumetric flask and stirred with PBS on a magnetic stirrer for $15 \mathrm{~min}$. The solution was filtered and diluted with PBS up to mark. $20 \mu \mathrm{L}$ volume of sample solution was injected into the column.

Eye drop solution containing $0.1 \%$ DIC sodium were used. Total amount of eye drop solution is $5 \mathrm{~mL}$. The solution was filtered and diluted with PBS up to mark. $20 \mu \mathrm{L}$ volume of sample solution was injected into the column.

\section{RESULTS AND DISCUSSION}

The aim of method validation was to confirm that the present method was suitable for its intended purpose as described in International Council for Harmonisation guidelines. ${ }^{28}$ The chromatograms of DKP, SA and DIC are given in Figure 1, 2, 3, respectively.

\section{Linearity}

The linearity of an analytical procedure is its ability to obtain test results which are directly proportional to the concentration of analyte in the sample. ${ }^{5}$ Calibration curve of DKP was constructed by plotting absorbance versus concentration which showed linearity over the concentration ranges of 0.39$20 \mu \mathrm{g} / \mathrm{mL}$ (Figure 4). Calibration curve of SA was constructed by plotting absorbance versus concentration which showed linearity over the concentration ranges of $0.0061-0.78 \mu \mathrm{g} / \mathrm{mL}$ (Figure 5). Calibration curve of DIC was constructed by plotting absorbance versus concentration which shows linearity over the concentration ranges of $0.0488-100 \mu \mathrm{g} / \mathrm{mL}$ in Figure 6. 


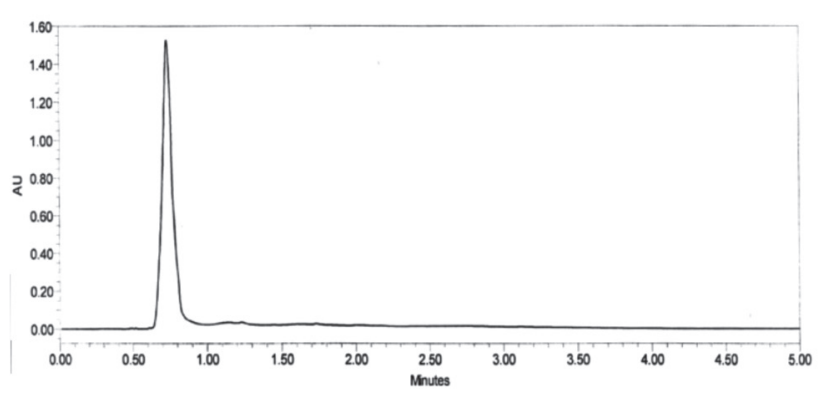

Figure 1. The peak of $1.25 \mu \mathrm{g} / \mathrm{mL}$ concentration of DKP in $\mathrm{pH} 7.4$ phosphate buffer solution, the A solvent was acetonitrile and the $\mathrm{B}$ solvent was $\mathrm{MeOH} /$ Water $(1 / 1)(\mathrm{v} / \mathrm{v})$, starting conditions were $98 \% \mathrm{~B}$, and within two $\min 30 \%$ $\mathrm{B}$ was employed, the final condition is $98 \% \mathrm{~B}$, The temperature was $25^{\circ} \mathrm{C}$, ultraviolet absorbance data were collected at $254 \mathrm{~nm}$, the flow rate was $0.25 \mathrm{~mL} / \mathrm{min}$

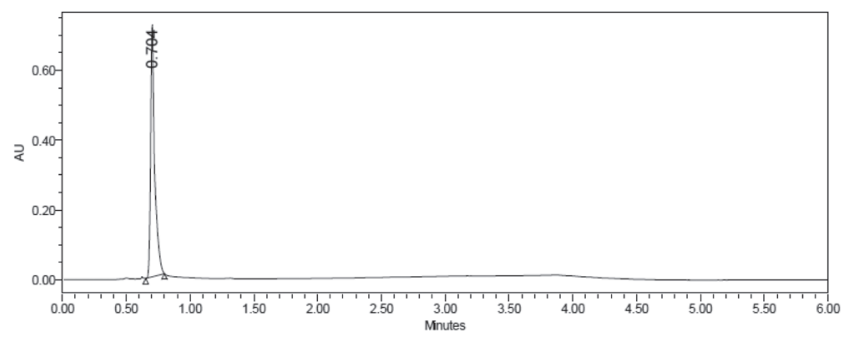

Figure 2. The peak of $1.56 \mu \mathrm{g} / \mathrm{mL}$ concentration of $\mathrm{SA}$ in $\mathrm{pH} 7.4$ phosphate buffer solution, the A solvent was acetonitrile and the $\mathrm{B}$ solvent was $\mathrm{MeOH} /$ Water $(1 / 1)(\mathrm{v} / \mathrm{v})$, starting conditions were $98 \% \mathrm{~B}$, and within two $\min 30 \%$ $\mathrm{B}$ was employed, the final condition is $98 \% \mathrm{~B}$, the temperature was $25^{\circ} \mathrm{C}$, ultraviolet absorbance data were collected at $292 \mathrm{~nm}$, the flow rate was $0.25 \mathrm{~mL} / \mathrm{min}$

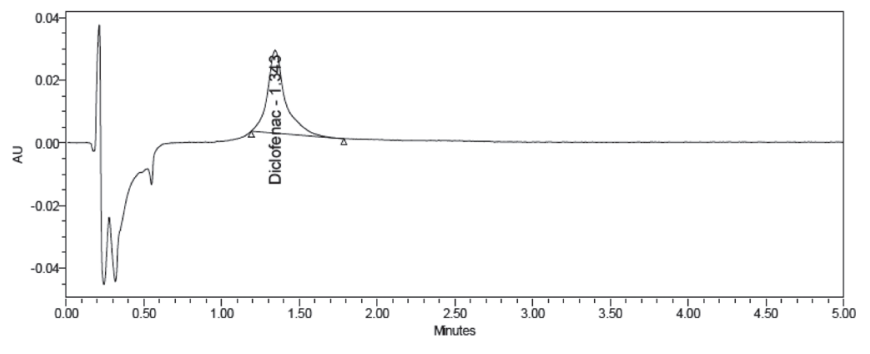

Figure 3. The peak of $3.125 \mu \mathrm{g} / \mathrm{mL}$ concentration of $\mathrm{DIC}$ in $\mathrm{pH} 7.4$ phosphate buffer solution, the $A$ solvent was acetonitrile and $B$ solvent was $50 \mathrm{mM}$ acetate buffer (1/1), ( $\mathrm{v} / \mathrm{v}) \mathrm{pH} 3.1$, the column temperature was stable at $25^{\circ} \mathrm{C}$, ultraviolet absorbance data were collected at $254 \mathrm{~nm}$

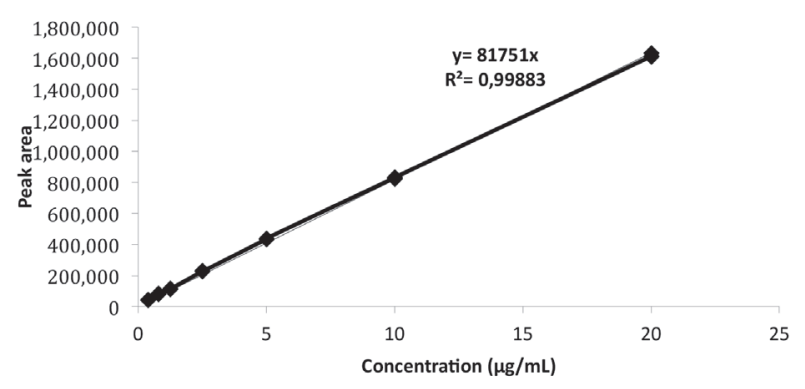

Figure 4. Calibration curve of dexketoprofen trometamol in $25 \% \mathrm{pH} 7.4$ phosphate buffer obtained by ultra high performance liquid chromatography method (calibration equations were obtained for a concentration range of $0.39-20 \mu \mathrm{g} / \mathrm{mL}$ )

\section{Accuracy}

The accuracy of an analytical method is the closeness of test results obtained by the method to the true value and is defined recovery. ${ }^{29}$ As you can see the accuracy results of DKP, SA and DIC in Table 2, 3, 4.

\section{Precision}

The precision of an analytical method is the agreement within a series of individual measurements of an analyte when the analytical procedure is applied repeatedly to multiple aliquots of a single homogeneous samples under the same conditions. ${ }^{19}$

Repeatability: In terms of method precision study of our experiment, $15 \mu \mathrm{g} / \mathrm{mL}$ solutions were injected into the system and the percentage of precision was evaluated. Shown in Table 5 shows, the percentage of mean precision value of DKP

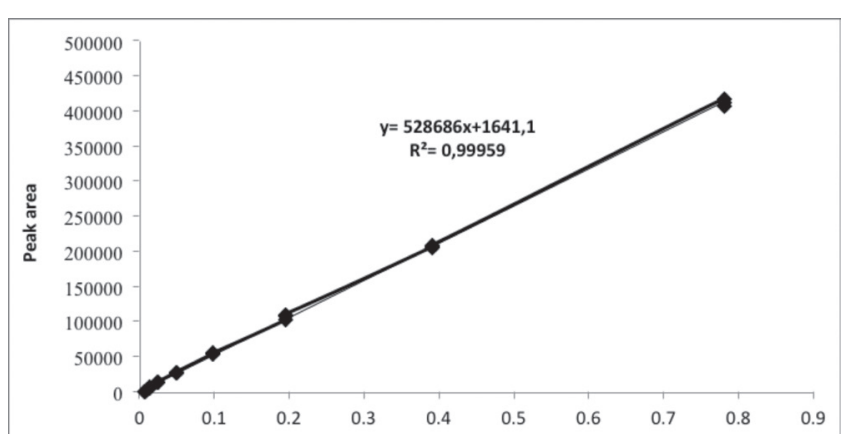

Figure 5. Calibration curve of salicylic acid in $25 \% \mathrm{pH} 7.4$ phosphate buffer obtained by ultra high performance liquid chromatography method (calibration equations were obtained for a concentration range of 0.0061 $0.78 \mu \mathrm{g} / \mathrm{mL}$ )

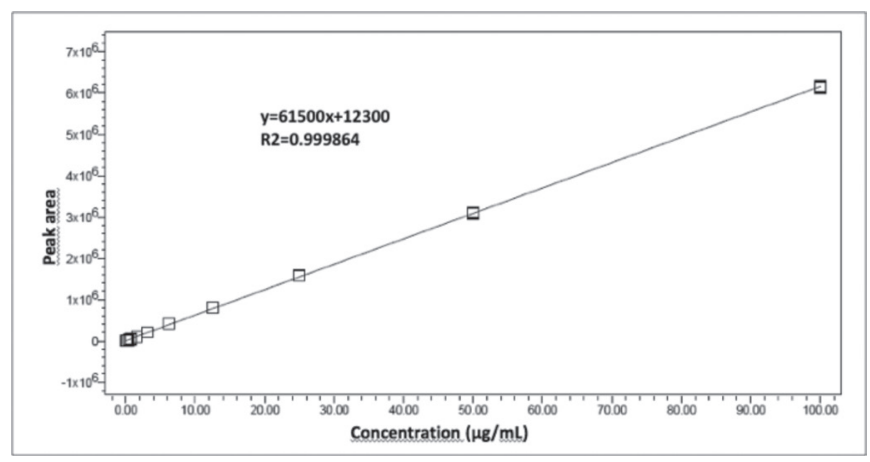

Figure 6. Calibration curve of diclofenac in $25 \% \mathrm{pH} 7.4$ phosphate buffer obtained by ultra high performance liquid chromatography method (calibration equations were obtained for a concentration range of 0.0488 $100 \mu \mathrm{g} / \mathrm{mL}$ )

Table 2. The calculated recovery amount of DKP from the solution in phosphate buffer

\begin{tabular}{llll}
$\begin{array}{l}\text { Percentage of } \\
\text { DKP in solution }\end{array}$ & $\begin{array}{l}\text { Concentration of } \\
\text { DKP in solution } \\
(\mu \mathrm{g} / \mathrm{mL})\end{array}$ & $\begin{array}{l}\text { Recovery of DKP } \\
(\mu \mathrm{g} / \mathrm{mL}) \pm \text { C.I. }\end{array}$ & $\begin{array}{l}\text { Coefficient of } \\
\text { variation } \%\end{array}$ \\
\hline 80 & 2.50 & $3.01 \pm 0.02$ & 0.56 \\
\hline 100 & 3.13 & $3.85 \pm 1.37$ & 1.16 \\
\hline 120 & 3.75 & $4.56 \pm 0.56$ & 0.48 \\
\hline
\end{tabular}

DKP: Dexketoprofen trometamol 
concentration level was 108.5 with standard deviation of 1.42 . As Table 6 shows, the percentage of mean precision value of SA concentration level was 90.1 with standard deviation of 1.48 . As Table 7, 8 shows, the percentage of mean precision value of high DIC concentration and less DIC concentration level were 110,101 with standard deviation of $1.74,1.31$, respectively. Since the percentage of precision has been found almost 100 and the standard deviation less than the acceptance criteria which is $2 \%$, the analysis system for the determination of assay is verified. Low values of standard deviation denoted very good repeatability of the measurement. Thus it was showing that the equipment used for the study was correct and hence the developed analytical method is highly repetitive.

Reproducibility: To evaluated the reproducibility parameters of DKP stock solution was prepared. Different concentrations of solution were also prepared from the stock solution by dilution. These solutions were measured by UPLC 6 times

\section{Table 3. The calculated recovery amount of SA from the solution} in phosphate buffer

\begin{tabular}{llll}
$\begin{array}{l}\text { Percentage of } \\
\text { SA in solution }\end{array}$ & $\begin{array}{l}\text { Concentration of } \\
\text { SA in solution } \\
(\mu \mathrm{g} / \mathrm{mL})\end{array}$ & $\begin{array}{l}\text { Recovery of SA } \\
(\mu \mathrm{g} / \mathrm{mL}) \pm \text { C.I. }\end{array}$ & $\begin{array}{l}\text { Coefficient of } \\
\text { variation } \%\end{array}$ \\
\hline 80 & 0.31 & $0.29 \pm 1.74$ & 1.96 \\
\hline 100 & 0.39 & $0.39 \pm 0.98$ & 1.03 \\
\hline 120 & 0.47 & $0.42 \pm 1.58$ & 1.84 \\
\hline
\end{tabular}

SA: Salicylic acid

Table 4. The calculated recovery amount of DIC from the solution in phosphate buffer

\begin{tabular}{llll}
$\begin{array}{l}\text { Percentage of } \\
\text { DIC in solution }\end{array}$ & $\begin{array}{l}\text { Concentration of } \\
\text { DIC in solution } \\
(\mu \mathrm{g} / \mathrm{mL})\end{array}$ & $\begin{array}{l}\text { Recovery of DIC } \\
(\mu \mathrm{g} / \mathrm{mL}) \pm \text { C.I. }\end{array}$ & $\begin{array}{l}\text { Coefficient of } \\
\text { variation } \%\end{array}$ \\
\hline 80 & 5.00 & $4.78 \pm 1.42$ & 1.85 \\
\hline 100 & 6.25 & $6.39 \pm 1.32$ & 1.78 \\
\hline 120 & 7.50 & $7.90 \pm 1.27$ & 1.46 \\
\hline
\end{tabular}

DIC: Diclofenac

Table 5. The results of precision study for $15.00 \mu \mathrm{g} / \mathrm{mL}$ DKP

Injection number of test Concentration $(\mu \mathrm{g} / \mathrm{mL}) \quad$ Percent value
solution

\begin{tabular}{lll}
\hline 1 & 16.60 & 110.65 \\
\hline 2 & 16.35 & 109.00 \\
\hline 3 & 16.21 & 108.09 \\
\hline 4 & 16.08 & 107.21 \\
\hline Mean & 16.10 & 107.33 \\
\hline SD & & 108.46 \\
\hline RSD \% & & 1.42 \\
\hline
\end{tabular}

DKP: Dexketoprofen trometamol, RSD: Relative standard deviation, SD: Standard deviation in 3 consecutive days (Table 9, 10, 11). The obtained to the average of peak heights were calculated standard deviation and standard error of the mean (SEM) values. The average of the concentration, standard deviation and SEM values were calculated. The recovery values from the commercial tablets, test tablets and eye drop, were found to be $103,114 \%, 134,118 \%$ and $111,104 \%$ for DKP, SA and DIC respectively. The precision of the chromatographic analysis in tablets and eye drop was determined at two concentrations of each active substance. The coefficients of variation were obtained by repeating the procedure three times for each sample as shown in Table 12, $13,14$.

\section{Specificity/Selectivity}

The specificity of an analytical method is its ability to measure accurately and specifically the analyte in the presence of components that may be expected to be present in the sample.19,30 Specificity was observed that the diluents did not interfere for the detection of DKP, SA or DIC.

\begin{tabular}{lll}
\multicolumn{3}{l}{ Table 6. The results of precision study for $0.47 \mu \mathrm{g} / \mathrm{mL}$ SA } \\
$\begin{array}{l}\text { Injection number of test } \\
\text { solution }\end{array}$ & $\begin{array}{l}\text { Concentration } \\
(\mu \mathrm{g} / \mathrm{mL})\end{array}$ & Percent value \\
\hline 1 & 0.42 & 90.06 \\
\hline 2 & 0.41 & 87.31 \\
\hline 3 & 0.42 & 90.53 \\
\hline 4 & 0.43 & 90.95 \\
\hline 5 & 0.43 & 91.61 \\
\hline 6 & 0.42 & 90.01 \\
\hline Mean & & 90.08 \\
\hline SD & 1.48 \\
\hline RSD \% & 1.64 \\
\hline SA:S
\end{tabular}

SA: Salicylic acid, RSD: Relative standard deviation, SD: Standard deviation

Table 7. The results of precision study for $15.00 \mu \mathrm{g} / \mathrm{mL}$ DIC (obtained in high DIC concentration)

Injection number of test Concentration $(\mu \mathrm{g} / \mathrm{mL}) \quad$ Percent value

solution

\begin{tabular}{lll}
\hline 1 & 16.31 & 108.72 \\
\hline 2 & 16.41 & 109.37 \\
\hline 3 & 16.57 & 110.49 \\
\hline 4 & 16.12 & 107.47 \\
\hline 5 & 16.83 & 112.23 \\
\hline Mean & 16.69 & 111.24 \\
\hline SD & & 109.92 \\
\hline RSD \% & & 1.74 \\
\hline
\end{tabular}

DIC: Diclofenac, RSD: Relative standard deviation, SD: Standard deviation 
Table 8. The results of precision study for $3.75 \mu \mathrm{g} / \mathrm{mL}$ DIC (obtained in less DIC concentration)

\begin{tabular}{lll}
$\begin{array}{l}\text { Injection number of test } \\
\text { solution }\end{array}$ & Concentration $(\mu \mathrm{g} / \mathrm{mL})$ & Percent value \\
\hline 1 & 3.75 & 99.88 \\
\hline 2 & 3.76 & 100.33 \\
\hline 3 & 3.85 & 102.61 \\
\hline 4 & 3.71 & 98.95 \\
\hline 5 & 3.81 & 101.53 \\
\hline 6 & 3.80 & 101.36 \\
\hline Mean & & 100.78 \\
\hline SD & & 1.31 \\
\hline RSD \% & 1.30 \\
\hline
\end{tabular}

DIC: Diclofenac, RSD: Relative standard deviation, SD: Standard deviation

Table 9. The results of reproducibility of DKP solutions

\begin{tabular}{lllllll}
$\begin{array}{l}\text { Concentration } \\
(\mu \mathrm{g} / \mathrm{mL})\end{array}$ & $\begin{array}{l}\text { First } \\
\text { day }\end{array}$ & $\begin{array}{l}\text { Second } \\
\text { day }\end{array}$ & $\begin{array}{l}\text { Third } \\
\text { day }\end{array}$ & Mean & SD & SEM \\
\hline 1.25 & 1.55 & 1.44 & 1.38 & 1.46 & 0.09 & 0.04 \\
\hline 2.50 & 2.46 & 2.37 & 2.32 & 2.38 & 0.07 & 0.03 \\
\hline 5.00 & 5.38 & 5.28 & 4.75 & 5.14 & 0.34 & 0.15 \\
\hline 10.00 & 10.49 & 10.06 & 9.30 & 9.95 & 0.61 & 0.27 \\
\hline 20.00 & 19.20 & 21.00 & 19.50 & 19.90 & 0.95 & 0.43 \\
\hline
\end{tabular}

DKP: Dexketoprofen trometamol, SD: Standard deviation, SEM: Standard error of the mean

Table 10. The results of reproducibility of SA solutions

\begin{tabular}{lllllll}
$\begin{array}{l}\text { Concentration } \\
(\mu \mathrm{g} / \mathrm{mL})\end{array}$ & $\begin{array}{l}\text { First } \\
\text { day }\end{array}$ & $\begin{array}{l}\text { Second } \\
\text { day }\end{array}$ & $\begin{array}{l}\text { Third } \\
\text { day }\end{array}$ & Mean & SD & SEM \\
\hline 0.08 & 0.07 & 0.10 & 0.07 & 0.08 & 0.02 & 0.01 \\
\hline 0.16 & 0.14 & 0.16 & 0.14 & 0.15 & 0.01 & 0.00 \\
\hline 0.31 & 0.28 & 0.26 & 0.28 & 0.27 & 0.01 & 0.01 \\
\hline 0.63 & 0.54 & 0.54 & 0.55 & 0.54 & 0.00 & 0.00 \\
\hline
\end{tabular}

SA: Salicylic acid, SD: Standard deviation, SEM: Standard error of the mean

\section{Table 11. The results of reproducibility of DIC solutions}

\begin{tabular}{lllllll}
$\begin{array}{l}\text { Concentration } \\
(\mu \mathrm{g} / \mathrm{mL})\end{array}$ & $\begin{array}{l}\text { First } \\
\text { day }\end{array}$ & $\begin{array}{l}\text { Second } \\
\text { day }\end{array}$ & $\begin{array}{l}\text { Third } \\
\text { day }\end{array}$ & Mean & SD & SEM \\
\hline 2.50 & 2.50 & 2.50 & 2.57 & 2.53 & 0.04 & 0.02 \\
\hline 10.00 & 11.60 & 11.31 & 10.52 & 11.14 & 0.56 & 0.25 \\
\hline 20.00 & 23.53 & 23.04 & 21.10 & 22.56 & 1.28 & 0.57 \\
\hline 40.00 & 47.16 & 46.16 & 42.57 & 45.30 & 2.41 & 1.08 \\
\hline 80.00 & 93.95 & 91.26 & 85.89 & 90.37 & 4.10 & 1.84 \\
\hline
\end{tabular}

DIC: Diclofenac, SD: Standard deviation, SEM: Standard error of the mean
The limit of detection and limit of quantitation

The limit of detection (LOD) and limit of quantitation (LOQ) tests for the procedure are performed on samples containing very low concentrations of analyses. LOD is defined as the lowest amount of analyze that can be detected above baseline noise; typically, three times the noise level. LOQ is defined as the lowest amount of analyze which can be reproducibly quantitated above the baseline noise. ${ }^{19,31} \mathrm{LOD}$ was found $0.00325 \mu \mathrm{g} / \mathrm{mL}$ and LOQ was found $0.00985 \mu \mathrm{g} / \mathrm{mL}$ for DKP. LOD was found $0.0027 \mu \mathrm{g} /$ $\mathrm{mL}$ and $\mathrm{LOQ}$ was found $0.0081 \mu \mathrm{g} / \mathrm{mL}$ for $\mathrm{SA}$. LOD was found

\begin{tabular}{|c|c|c|c|}
\hline $\begin{array}{l}\text { The commercial tablet } \\
\text { concentration of DKP } \\
(\mu \mathrm{g} / \mathrm{mL})\end{array}$ & $\begin{array}{l}\text { Injection } \\
\text { time of test } \\
\text { solution }\end{array}$ & $\begin{array}{l}\text { Found } \\
\text { concentration } \\
\text { of DKP }(\mu \mathrm{g} / \mathrm{mL})\end{array}$ & $\%$ Recovery \\
\hline \multirow{6}{*}{1.56} & 1 & 1.63 & 104.49 \\
\hline & 2 & 1.58 & 101.28 \\
\hline & 3 & 1.59 & 101.92 \\
\hline & Mean & & 102.56 \\
\hline & SD & & 1.70 \\
\hline & RSD \% & & 1.65 \\
\hline \multirow{6}{*}{12.50} & 1 & 14.20 & 113.60 \\
\hline & 2 & 14.10 & 112.80 \\
\hline & 3 & 14.30 & 114.40 \\
\hline & Mean & & 113.60 \\
\hline & SD & & 0.80 \\
\hline & RSD \% & & 0.70 \\
\hline
\end{tabular}

DKP: Dexketoprofen trometamol, SD: Standard deviation, RSD: Relative standard deviation

\section{Table 13. The recovery results of SA from tablet formulation}

The test tablet Injection Found concentration \% Recovery concentration of SA time of test of $S A(\mu \mathrm{g} / \mathrm{mL})$

$(\mu \mathrm{g} / \mathrm{mL})$ solution

0.03

\begin{tabular}{lll}
\hline 1 & 0.04 & 136.52 \\
\hline 2 & 0.04 & 133.11 \\
\hline 3 & 0.04 & 133.11 \\
\hline Mean & & 134.24 \\
\hline RSD \% & & 1.97 \\
\hline 1 & 0.57 & 1.47 \\
\hline 2 & 0.58 & 121.60 \\
\hline 3 & 0.52 & 123.09 \\
\hline Mean & & 110.29 \\
\hline SD & & 118.33 \\
\hline RSD \% & & 7.00 \\
\hline
\end{tabular}

SA: Salicylic acid, SD: Standard deviation, RSD: Relative standard deviation 
Table 14. The recovery results of DIC sodium from eye drop formulation

\begin{tabular}{|c|c|c|c|}
\hline $\begin{array}{l}\text { The commercial eye } \\
\text { drop concentration of } \\
\text { DIC }(\mu \mathrm{g} / \mathrm{mL})\end{array}$ & $\begin{array}{l}\text { Injection } \\
\text { number of } \\
\text { test solution }\end{array}$ & $\begin{array}{l}\text { Found } \\
\text { concentration } \\
\text { of DIC }(\mu \mathrm{g} / \mathrm{mL})\end{array}$ & $\%$ Recovery \\
\hline \multirow{6}{*}{1.56} & 1 & 1.75 & 112.18 \\
\hline & 2 & 1.72 & 110.26 \\
\hline & 3 & 1.73 & 110.90 \\
\hline & Mean & & 111.11 \\
\hline & SD & & 0.98 \\
\hline & RSD \% & & 0.88 \\
\hline \multirow{6}{*}{50.00} & 1 & 51.50 & 103.00 \\
\hline & 2 & 52.40 & 104.80 \\
\hline & 3 & 51.80 & 103.60 \\
\hline & Mean & & 103.80 \\
\hline & SD & & 0.92 \\
\hline & RSD \% & & 0.88 \\
\hline
\end{tabular}

DIC: Diclofenac, SD: Standard deviation, RSD: Relative standard deviation

$0.0304 \mu \mathrm{g} / \mathrm{mL}$ and LOQ was found $0.0920 \mu \mathrm{g} / \mathrm{mL}$ for DIC. $\mathrm{LOD}=(3.3 \times \sigma) / \mathrm{S}$

$L O Q=(10 \times \sigma) / S$

$\sigma:$ The standard deviation of the lowest concentration in the calibration range,

S: The slope of the calibration curve (to find the slope of the calibration curve has equation common calibration and taken his slope).

\section{CONCLUSION}

A simple, precise, accurate, reproducible, highly sensitive and effective stability indicating UPLC method was developed and validated for quantitative determination of DKP, SA and DIC. The method was validated for accuracy, precision, specificity, and linearity. The developed method has LOD and LOQ values are $0.00325 \mu \mathrm{g} / \mathrm{mL}$ and $0.00985 \mu \mathrm{g} / \mathrm{mL}$ for $D K P$, respectively. The $L O D$ and $L O Q$ values are $0.0027 \mu \mathrm{g} / \mathrm{mL}$ and $0.0081 \mu \mathrm{g} / \mathrm{mL}$ for SA, respectively. The LOD and LOQ values are $0.0304 \mu \mathrm{g} /$ $\mathrm{mL}$ and $0.0920 \mu \mathrm{g} / \mathrm{mL}$ for DIC, respectively. In this study, the high recovery and low relative standard deviation confirm the suitability of the method for determination of DKP, SA and DIC in pharmaceutical dosage forms. In conclusion, this method can be used for the routine determination of DKP, SA and DIC in pure and pharmaceutical formulations.

Conflict of Interest: No conflict of interest was declared by the authors.

\section{REFERENCES}

1. Chaudhari BG, Trivedi JB. Simultaneous spectrophotometric estimation of thiocolchicoside and dexketoprofen trometamol in pharmaceutical dosage form. Int J Biomed Advance Res. 2012;3:179.
2. Bhusari VK, Dhaneshwar SR. Development of a validated stability-indicating HPLC assay method for dexketoprofen trometamol. Int J Pharmacy Pharmaceutical Sci. 2012;4:321-326.

3. Jain PM, Patil RR, Mhaske AJ, Gawad JB, Patil VK. Reversed-phase high performance liquid chromatographic method for simultaneous estimation of dexketoprofen and dicyclomine in bulk and tablet dosage form. Int J Universal Pharmacy Bio Sci. 2013;2:284-291.

4. Harde MT, Dharam DL, Jadhav SB, Balap AR. RP-HPLC method for simultaneous estimation of Thiocolchicoside and Dexketoprofen in bulk and tablet dosage form. Int J Pharm Tech Res. 2012;4:1797-1802.

5. Archana K, Vikas P. Development and Validation of Reversed Phase High Performance Liquid Chromatographic Method for Estimation of Dexketoprofen Trometamol in Bulk and Tablet Dosage Form. American J Phyto Clinic Ther. 2013;395-400.

6. Tilo Grosser ES, FitzGerald GA. Anti-Inflammatory, antipyretic, and analgesic agents. In: Goodman and Gilman's the pharmacological basis of therapeutics. Ed: L.L. Brunton, 12th ed. New York: McGraw-Hill Co; pp. 2011;977-82.

7. Daintith EJ. Aspirin. Oxford University Press; 2008. Available from: URL http:// www.oxfordreference.com/views/ENTRY. html?subview=Main\&entry=t81. e4554. Accessed August 17, 2012.

8. Palleros DR. Experimental organic chemistry. New York: John Wiley and Sons, 2000.

9. Lipster D, Kragballe K, Saurat JH, Other topical medications. In: Dermatology. Ed(s): J.L. Bolognia, R.P. Rapini, 1st ed. Philadelphia: Elsevier Limited, p. 2062, 2003.

10. Madan RK, Levitt J. A review of toxicity from topical salicylic acid preparations. J Am Acad Dermatol. 2014;70:788-792.

11. Bhattacharyaa SS, Banerjeeb S, Ghosha AK, Chattopadhyayb P, Vermaa A, Ghosh A. A RP-HPLC method for quantification of diclofenac sodium released from biological macromolecules. Int J Biol Macromol. 2013;58:354-359.

12. Dhaneshwar SR, Bhusari VK. Validated HPLC Method for Simultaneous Quantitation of Diclofenac Sodium and Misoprostol in Bulk Drug and Formulation. Der Chemica Sinica. 2010;1:110-118.

13. Sinkó B, Garrigues TM, Balogh GT, Nagy ZK, Tsinman O, Avdeef A, TakacsNovak K. Skin-PAMPA: A new method for fast prediction of skin penetration. Eur J Pharm Sci. 2012;45:698-707.

14. Karadzovska D, Riviere JE. Assessing vehicle effects on skin absorption using artificial membrane assays. Eur J Pharm Sci. 2013;50:569-576.

15. Miki R, Ichitsuka Y, Yamada T, Kimura S, Egawa Y, Seki T, Juni K, Ueda $\mathrm{H}$, Morimoto $\mathrm{Y}$. Development of a membrane impregnated with a poly(dimethylsiloxane)/poly(ethylene glycol) copolymer for a high-throughput screening of the permeability of drugs, cosmetics, and other chemicals across the human skin. Eur J Pharm Sci. 2015;66;41-49.

16. Garcia-Arieta A, Gordon J, Gwaza L, Mangas-Sanjuan V, Alverez C, Torrado JJ. [Agitation Rate and Time for Complete Dissolution in BCS Biowaivers Based on Investigation of a BCS Biowaiver for Dexketoprofen Tablets]. Mol Pharmaceutics. 2015;12:3194-3201.

17. Wu CY, Benet LZ. Predicting Drug Disposition via Application of BCS: Transport/Absorption/ Elimination Interplay and Development of a Biopharmaceutics Drug Disposition Classification System. Pharm Research. 2005;22:11-23

18. Chuasuwan B, Binjesoh V, Polli JE, Zhang $H$, Amidon GL, Junginger HE, Midha KK, Shah VP, Stavchansky S, Dressman JB, Barends DM. Biowaiver Monographs for Immediate Release Solid Oral Dosage Forms: Diclofenac Sodium and Diclofenac Potassium. J Pharm Sci. 2009;98:1206-1219. 
19. Green JM. A Practical Guide to Analytical Method Validation. Analytical Chemistry. 1996;68:305A-309A.

20. ICH Harmonised Tripartite Guideline, Validation of Analytical Methods: Definitions and Terminology, ICH Topic Q2B, 1-9 (6 November 1996).

21. Dhaneshwar SR, Jagtap VN. Development and validation of RP-HPLC-PDA method for simultaneous determination of dexketoprofen and thiocolchicoside in pharmaceutical dosage form. J Pharm Res. 2013;6:604-608.

22. Pavan Kumar VV, Vinu MCA, Ramani AV, Mullangi R, Srinivas NR. Simultaneous quantitation of etoricoxib, salicylic acid, valdecoxib, ketoprofen, nimesulide and celecoxib in plasma by high-performance liquid chromatography with UV detection. Biomed Chromatogr. 2006;20:125-132.

23. Matsuura H, Aoi A, Satou C, Nakaya M, Masuta C, Nabeta K. Simultaneous UPLC MS/MS analysis of endogenous jasmonic acid, salicylic acid, and their related compounds. Plant Growth Regul. 2009;57:293-301.

24. Diez L, Livertoux MH, Stark AA, Wellman-Rousseau M, Leroy P. Highperformance liquid chromatographic assay of hydroxyl free radical using salicylic acid hydroxylation during in vitro experiments involving thiols. J Chromatogr B, Biomed Sci App. 2001;763:185-193.

25. Gámiz-Gracia L, Luque de Castro MD. An HPLC Method for the Determination of Vitamin B1, Caffeine, Acetylsalicylic Acid, and The Impurities of Salicylic Acid in a Pharmaceutical Preparation. J Liq Chrom Rel Technol. 1997;20:2123-2133.
26. Gowramma B, Rajan S, Muralidharan S, Meyyanathan SN, Suresh B. A Validated Rp-HPLC Method for Simultaneous Estimation of Paracetamol and Diclofenac Potassium in Pharmaceutical Formulation Int $\mathrm{J}$ Chem Tech Res. 2010;2:676-680.

27. Nasir F, lqbal Z, Khan A, Ahmada L, Shaha Y, Khan AZ, Khan JA, Khan S. Simultaneous determination of timolol maleate, rosuvastatin calcium and diclofenac sodium in pharmaceuticals and physiological fluids using HPLCUV. J Chromatogr B. 2011;879:3434-3443.

28. ICH-Q2 (R1) International Conference on Harmonisation of Technical Requirements for Registration of Pharmaceuticals for Humen Use 2005; http//www.ich.org [Accessed: 20.02. 2015].

29. Lindholm J, Johansson M, Fornstedt T. Guidelines for Analytical Method Development and Validation of Biotechnological Synthesis of Drugs Production of a Hydroxyprogesterone as Model. J Chromatogr B Analyt Technol Biomed Life Sci. 2003;791:323-336.

30. Hacıoğlu A, Çıtlak A, Karakuş S. Development and validation of an HPLC method for determination of nateglinide in drug substances. Marmara Pharm. J 2015;19:103-108.

31. Üstündağ Okur N, Çağlar EŞ, Yozgatlı V. Development and Validation of an HPLC Method for Voriconazole Active Substance in Bulk and its Pharmaceutical Formulation. Marmara Pharm J. 2016;20:79-85. 